\title{
Leaf consumption and duration of instars of the cassava defoliator Erinnyis ello (L., 1758) (Lepidoptera, Sphingidae)
}

\author{
Dirceu Pratissoli ${ }^{1}$ \\ José Cola Zanúncio ${ }^{2}$ \\ Reginaldo Barros $^{3}$ \\ Harley Nonato de Oliveira ${ }^{1,4}$
}

\begin{abstract}
The objectives of this research were to evaluate leaf consumption and the developmental time of the larvae of Erynnyis ello (L., 1758) (Lepidoptera, Sphingidae) reared on cassava, in order to obtain information for the integrated management of this pest. The larvae were reared on excised cassava leaves in Petri dishes and later in gerbox, and kept in chambers at $24 \pm 2{ }^{\circ} \mathrm{C}$ and $75 \pm 10 \% \mathrm{RH}$. The total leaf area consumed by the larva to complete its development was 589.67 $\mathrm{cm}^{2}$; each of the five instars consumed, respectively: $1.89 \mathrm{~cm}^{2} ; 5.74 \mathrm{~cm}^{2} ; 17.48 \mathrm{~cm}^{2} ; 76.66 \mathrm{~cm}^{2}$; and $487.90 \mathrm{~cm}^{2}$. The consumption by the first three instars was insignificant, and did not reach $5 \%$ altogether; the $4^{\text {th }}$ represented $13 \%$; the $5^{\text {th }}$ presented a consumption significantly higher, about $82.7 \%$. The total time for the larval development was 22.61 days, and the duration for each of the five larval instar was, respectively: $4.35 ; 3.19 ; 3.32 ; 4.52$; and 4.94 days. The pre-pupal period lasted 2.29 days. Since the highest consumption is by the $5^{\text {th }}$ instar larva, the control should be applied before this age to avoid heavier damages to the cassava crop.
\end{abstract}

Keywords. Cassava; larval development; leaf consumption; pest damage.

\section{INTRODUCTION}

The cassava plant had been cultivated by American natives long before the New World was discovered. Those people spread this crop to the whole American Continent. The Portuguese and the Spaniards later started the cultivation of cassava in other continents, especially in Asia and Africa (LoRENZI et al. 1996; BEZERRA 2000). The cassava crop can be linked to the historical, social and economical development of the Brazilian people as a subsistence and typical culture due to its easy cultivation, adaptation to poor soils and good resistance to diseases. The cassava has been produced almost exclusively in small properties (DUARTE 1997; BeZERRA 2000).

World production of cassava is estimated in about 120 million tons a year. Larger areas are cultivated with this culture in the tropics where it is considered the third most important agricultural product (LoRENZI et al. 1996). Nigeria and Thailand are the world largest producers of cassava, ranking as the sixth food product in volume, after wheat, rice, corn, potato and barley. Brazil is the third largest world producer of cassava with about 20 million tons of roots per year. From the volume produced about $60 \%$ is used for human and animal consumption, $30 \%$ as flour and starch, and $10 \%$ for pharmaceutical, textile and chemical industries (Ternes et al. 1984; BEZERRA 2000).

The main pest problem on cassava crops is the defoliator Erinnyis ello (L. 1758) (Lepidoptera: Sphingidae) which is known as the "mandarová-da-mandioca" in Brazil. This pest can cause $100 \%$ defoliation of cassava plants; it also feeds on tender parts of the plants (TeRNes et al.1984; Gallo et al. 1988). Such defoliation can have a high impact on cassava production when it reaches $100 \%$ in six month old plants of "Mantiqueira" and "Santa Catarina" cultivars. Defoliation reduces significantly the total weight production of roots and branches (CARVAlHo 1980).

This species is also a pest of rubber trees and its damage in nurseries of this plant is significantly important. An infestation of 16 caterpillars per 10 plants of rubber trees affects the normal growth of $52.2 \%$ of the plants in the nursery (Celestino Filho et al. 1982).

Erinnyis ello generally presents five instars, this number is not constant. The number of instars can vary due to the impact

1. Centro de Ciências Agrárias da Universidade Federal do Espírito Santo. 29500-000 Alegre-ES, Brasil. E-mail:dirceu@npd.ufes.br

2. Departamento de Biologia Animal da Universidade Federal de Viçosa. 36570-000 Viçosa-MG, Brasil.

3. Departamento de Agronomia/Fitossanidade da Universidade Federal Rural de Pernambuco. 52171-900 Recife-PE, Brasil.

4. Bolsista PROFIX do CNPq-Brasil. E-mail:hnoliveira@insecta.ufv.br 
of biotic and abiotic factors such as hereditary, rearing techniques, temperature, nutrition, sex, and intrinsic characters of each species (Silveira Neto et al. 1976; PARRA \& HADDAD 1989; PizZAmiglio 1991; PARRA 2000).

The objective of this research was to evaluate leaf consumption and duration of the instars and of the larval and pre-pupal periods of E. ello fed with cassava leaves in laboratory conditions.

\section{MATERIAL AND METHODS}

This research was developed at the Laboratory of Entomology of the Centro de Ciências Agrárias da Universidade Federal do Espírito Santo (CCAUFES) of the Universidade Federal do Espírito Santo (UFES) in the County of Alegre, State of Espírito Santo, Brazil, at a temperature of $24 \pm 2{ }^{\circ} \mathrm{C}$, relative humidity of $75 \pm 10 \%$ and photophase without control.

Eggs of E. ello were collected from cassava plants in the Escola Agrotécnica Federal de Alegre, in Alegre. After removed from the plants, these eggs were taken to the laboratory and maintained in gerbox plastic boxes until the emergence of caterpillars. Newly emerged caterpillars were transferred daily to individual Petri dishes of $20 \times 5 \mathrm{~cm}$, until they reached third instar when they were placed in gerbox boxes due to their bigger size.

The larvae of $E$. ello were maintained in six groups with ten caterpillars of similar age to obtain an uniform development, and the dead larvae were discarded. Only thirty one caterpillars that reached pupal stage were considered in the analysis.

Consumption of cassava leaves per caterpillar was evaluated using fresh leaves of the cultivars "Mantiqueira". Each caterpillar received one cassava leaf daily with its stalk inserted in moistened cotton to keep it fresh. To determine the leaf consumption per caterpillar, the leaf area was previously measured, and again at the moment of replacement by fresh ones. Leaf consumption during each instar and of complete larval stage was evaluated.

Duration of each instar and of the total larval period and pre-pupal stage were also evaluated.

\section{RESULTS}

The larvae of $E$. ello passed through five instars. The largest leaf consumption occurred during the fifth instar, and the larvae stop feeding when reach the pre-pupal stage.

Leaf consumption during the first instar was $1.89 \mathrm{~cm}^{2}$ (variation from 1.2 to $3.0 \mathrm{~cm}^{2}$ ) what corresponded to $0.32 \%$ of the total leaf area consumed during the larval stage. During the second instar the leaf consumption was $5.74 \mathrm{~cm}^{2}$ (3.4 to 8.0 ), what was almost three times higher than that of the first instar and it corresponded to $0.97 \%$ of the total leaf consumption of the larval stage. The third instar consumed $17.48 \mathrm{~cm}^{2}(11.7$ to 30.2 ) what corresponded to $2.96 \%$ of the total leaf consumption and about three times more than the previous instar. The fourth instar consumed $76.66 \mathrm{~cm}^{2}$ (45.8 to 111.3 ), which representing
$13 \%$ of the total leaf area consumed, this value was 4.4 times higher than that of the previous instar. Leaf consumption during the last instar was $487.90 \mathrm{~cm}^{2}$ (324.0 to 620.0) representing $82.75 \%$ of the total leaf consumption during the larval stage, it was 6.4 times higher than that of the fourth instar (Table 1 and Fig. 1). The total leaf consumed per caterpillar during the larval stage was $589.67 \mathrm{~cm}^{2}$ (variation from 389.7 to $756.6 \mathrm{~cm}^{2}$ ) (Table 1).

Caterpillars of E. ello completed the first instar in an average of 4.35 days (variation from 3.0 to 8.0 days); the second instar lasted 3.19 days (2.0 to 4.0 ); the third instar lasted 3.32 days (2.0 to 4.0); the fourth instar lasted 4.52 days (2.0 to 6.0) and the fifth was completed in 4.94 days (4.0 to 7.0).

The total duration of the larval stage was 20.32 days and the pre-pupal phase 2.29 days. This shows that the pre-pupal period of this insect was relatively short and it varied from one to three days.

\section{DISCUSSION}

Bellotti \& Schoonhovev (1978) reported a total leaf consumption of $1,107 \mathrm{~cm}^{2}$ per caterpillar of $E$. ello which was much higher than that found in this research. However, those authors obtained $75.0 \%$ of the total leaf consumption during the fifth instar what was similar to the value registered in the present research, and also to that found by CARVALHO (1980), which was $82.34 \%$. The highest leaf consumption during the last instars is related to a more rapid growth of the caterpillars and to the storage of nutrient reserves for posterior transformation processes during the pupal phase, as well as for the adult since this does not feed on protein but only on energetic material (PANIZZI \& PARRA 1991; PARRA 2000). This fact was also reported by BoLDT et al. (1975) who found a soybean leaf consumption of $119,114,155$ and $336 \mathrm{~cm}^{2}$ during the last instars of the noctuid caterpillars Trichoplusia ni (Huebner, 1802), Pseudoplusia includens (Walker), Heliothis virescens (Fabricius, 1781) and Heliothis zea (Boddie, 1850).

Fig. 1. Leaf area (\%) of cassava leaves consumed during each instar by the defoliator Erinnyis ello in laboratory at $24 \pm 2{ }^{\circ} \mathrm{C}$ and $75 \pm 10 \%$ relative humidity.

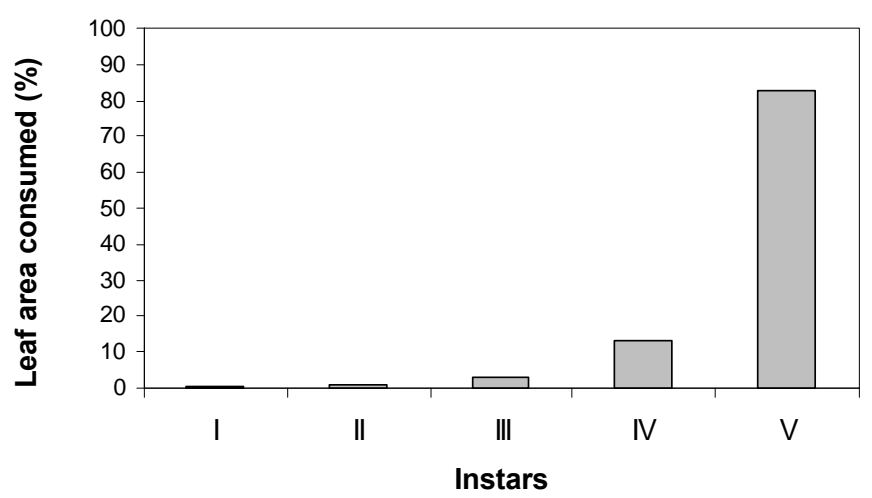


Table 1. Area of cassava leaves $\left(\mathrm{cm}^{2}\right)$ consumed per caterpillar (C) and mean duration, in days (D), of the instars of the cassava defoliator Erinnyis ello, in laboratory at $24 \pm 2{ }^{\circ} \mathrm{C}$ and $75 \pm 10 \%$ relative humidity .

\begin{tabular}{|c|c|c|c|c|c|c|c|c|c|c|c|c|c|}
\hline \multirow{2}{*}{ Caterpillar } & \multicolumn{2}{|c|}{ Instar I } & \multicolumn{2}{|c|}{ Instar II } & \multicolumn{2}{|c|}{ Instar III } & \multicolumn{2}{|c|}{ Instar IV } & \multicolumn{2}{|c|}{ Instar V } & \multicolumn{2}{|c|}{ Total } & \multirow{2}{*}{$\begin{array}{l}\text { Pre- } \\
\text { pupa }\end{array}$} \\
\hline & $\mathrm{C}$ & $\mathrm{D}$ & $\mathrm{C}$ & $\mathrm{D}$ & $\mathrm{C}$ & $\mathrm{D}$ & $\mathrm{C}$ & $\mathrm{D}$ & $\mathrm{C}$ & $\mathrm{D}$ & $\mathrm{C}$ & D & \\
\hline 01 & 1.7 & 5 & 7.2 & 4 & 12.7 & 3 & 50.0 & 5 & 504.0 & 6 & 575.6 & 23 & 2 \\
\hline 02 & 1.8 & 5 & 7.0 & 4 & 12.4 & 3 & 49.0 & 5 & 503.0 & 6 & 573.2 & 23 & 2 \\
\hline 03 & 2.2 & 5 & 8.0 & 4 & 13.0 & 3 & 49.7 & 5 & 502.6 & 6 & 575.4 & 23 & 2 \\
\hline 04 & 1.5 & 4 & 4.0 & 3 & 13.8 & 4 & 46.4 & 4 & 324.0 & 6 & 389.7 & 21 & 3 \\
\hline 05 & 2.1 & 5 & 4.0 & 3 & 13.8 & 4 & 46.0 & 4 & 504.0 & 7 & 569.5 & 23 & 3 \\
\hline 06 & 1.6 & 7 & 4.0 & 3 & 12.5 & 3 & 49.8 & 5 & 504.0 & 7 & 572.0 & 22 & 3 \\
\hline 07 & 1.6 & 4 & 4.0 & 3 & 24.4 & 4 & 59.6 & 5 & 492.0 & 6 & 581.6 & 22 & 3 \\
\hline 08 & 1.0 & 5 & 8.2 & 4 & 11.9 & 3 & 77.2 & 5 & 468.0 & 5 & 566.3 & 22 & 3 \\
\hline 09 & 1.4 & 4 & 3.4 & 4 & 10.2 & 3 & 98.2 & 6 & 468.0 & 5 & 581.2 & 22 & 2 \\
\hline 10 & 1.2 & 4 & 5.8 & 4 & 12.4 & 3 & 45.8 & 5 & 502.5 & 6 & 567.7 & 22 & 2 \\
\hline 11 & 2.1 & 8 & 8.6 & 3 & 30.2 & 3 & 67.0 & 3 & 420.0 & 4 & 527.9 & 21 & 2 \\
\hline 12 & 1.9 & 5 & 6.4 & 3 & 21.8 & 4 & 110.5 & 5 & 420.0 & 4 & 560.6 & 21 & 2 \\
\hline 13 & 1.8 & 4 & 4.6 & 4 & 15.8 & 3 & 110.5 & 6 & 620.0 & 5 & 752.7 & 22 & 1 \\
\hline 14 & 1.5 & 4 & 7.4 & 4 & 15.5 & 3 & 91.5 & 5 & 457.0 & 5 & 573.3 & 21 & 2 \\
\hline 15 & 2.4 & 6 & 5.4 & 3 & 21.9 & 4 & 111.0 & 4 & 420.0 & 4 & 560.7 & 21 & 2 \\
\hline 16 & 2.7 & 4 & 6.8 & 4 & 15.8 & 4 & 111.3 & 5 & 620.0 & 5 & 756.6 & 22 & 3 \\
\hline 17 & 3.0 & 4 & 7.0 & 4 & 14.8 & 3 & 110.9 & 6 & 620.0 & 5 & 755.7 & 22 & 3 \\
\hline 18 & 1.6 & 8 & 7.0 & 3 & 21.6 & 3 & 110.3 & 4 & 560.0 & 4 & 700.5 & 22 & 2 \\
\hline 19 & 2.6 & 4 & 4.4 & 3 & 21.7 & 4 & 70.8 & 4 & 420.0 & 4 & 519.5 & 19 & 2 \\
\hline 20 & 2.5 & 3 & 7.4 & 4 & 23.2 & 4 & 89.0 & 4 & 420.0 & 4 & 542.1 & 19 & 2 \\
\hline 21 & 2.0 & 4 & 6.8 & 3 & 20.5 & 4 & 71.5 & 4 & 420.0 & 4 & 520.8 & 19 & 2 \\
\hline 22 & 1.9 & 3 & 4.8 & 3 & 12.1 & 3 & 69.0 & 5 & 466.5 & 5 & 554.3 & 19 & 2 \\
\hline 23 & 1.9 & 4 & 5.7 & 3 & 11.7 & 2 & 61.3 & 5 & 463.5 & 5 & 544.1 & 19 & 2 \\
\hline 24 & 2.7 & 4 & 6.7 & 2 & 20.3 & 3 & 79.5 & 4 & 620.0 & 5 & 729.2 & 18 & 2 \\
\hline 25 & 2.1 & 4 & 6.2 & 3 & 20.0 & 4 & 61.5 & 2 & 580.0 & 5 & 669.8 & 18 & 3 \\
\hline 26 & 1.7 & 4 & 5.1 & 2 & 20.2 & 3 & 73.0 & 4 & 420.0 & 4 & 520.0 & 17 & 2 \\
\hline 27 & 1.6 & 4 & 4.2 & 2 & 20.3 & 3 & 71.5 & 4 & 420.0 & 4 & 517.6 & 17 & 2 \\
\hline 28 & 1.2 & 3 & 4.4 & 3 & 20.0 & 3 & 81.5 & 4 & 418.0 & 4 & 525.1 & 17 & 2 \\
\hline 29 & 1.3 & 3 & 3.4 & 2 & 21.9 & 4 & 72.0 & 4 & 420.0 & 4 & 518.6 & 17 & 2 \\
\hline 30 & 1.7 & 3 & 6.2 & 3 & 21.0 & 3 & 81.0 & 4 & 578.5 & 5 & 688.4 & 18 & 3 \\
\hline 31 & 1.7 & 4 & 4.0 & 2 & 15.0 & 3 & 100.2 & 5 & 569.5 & 4 & 690.4 & 18 & 3 \\
\hline Total & 58.50 & 135 & 178.1 & 99 & 542.0 & 102 & 2376.5 & 140 & 15125.0 & 153 & 18280.1 & 630 & 71 \\
\hline Mean & 1.89 & 4.35 & 5.74 & 3.19 & 17.48 & 3.32 & 76.66 & 4.52 & 487.90 & 4.94 & 589.67 & 20.32 & 2.29 \\
\hline Range & $\begin{array}{l}1.0- \\
3.0\end{array}$ & $3-8$ & $\begin{array}{l}3.4- \\
8.6 \\
\end{array}$ & $2-4$ & $\begin{array}{l}10.2- \\
30.2\end{array}$ & $2-4$ & $\begin{array}{r}46.0- \\
111.3\end{array}$ & $2-6$ & $\begin{array}{l}324.0- \\
620.0\end{array}$ & $4-7$ & $\begin{array}{l}389.7- \\
756.6\end{array}$ & $17-23$ & $1-3$ \\
\hline
\end{tabular}

Those numbers represent about $90.0 \%$ of the total leaf consumed by these insects during their last instar.

Studies about damage by insect pests are important because they allow to predict its impact on the crop production. BELLOTTI \& Schoonhovev (1978) showed that the defoliation of cassava plants has a high impact on cassava production when the damage occurs when the plants are six to 10 months old. They obtained $1.107 \mathrm{~cm}^{2}$ of consumed area of cassava leaves per caterpillar, and observed that a relatively high population of $E$. ello can be tolerated by these plants. This can be explained by the fact that cassava plants do not present significant losses of root production even with defoliation up to about $80 \%$.

\section{CONCLUSION}

Caterpillars of E. ello present the higher leaf consumption during the fifth instar. For this reason, the pest control can be directed to the last instars, and only when the population reaches high number of individuals. The biological dates can be useful to predict the insect infestation period and to establish the most adequate integrated pest management strategies.

Acknowledgements. To Conselho Nacional de Desenvolvimento Científico e Tecnológico (CNPq) for grants. 


\section{REFERENCES}

Bellotti, A. \& A. Schoonhovev. 1978. Plagas de la Yuca y su control Centro Internacional de Agricultura Tropical - CIAT, Colombia. $73 \mathrm{p}$.

Bezerra, J. A. 2000. Mandioca: A raiz do Brasil. Globo Rural 175: $42-$ 50 .

Boldt, P. E.; K. D. Biever \& C. M. Ignoffo. 1975. Lepidopteran Pests of Soybeans : Consumption of Soybean Foliage and Pods and Development Time. Journal of Economic Entomology 98: 480482 .

Carvalho, C. F. 1980. Aspectos biológicos, técnica para obtenção de ovos em condições de laboratório e avaliação de danos de Erinnyis ello (L., 1958) (Lepidoptera-Sphingidae) em mandioca em condições de campo. Dissertação de Mestrado. Piracicaba, ESALQ/USP, 87p.

Celestino Filho, P.; A. G. Rossetti; O. G. Rocha Neto \& F. E. L. Magalhães. 1982. Avaliação de danos de Erinnys ello (L., 1978), em viveiros de seringueira. Pesquisa Agropecuária Brasileira 17: 981-983.

Duarte, J. 1997. Mandioca mais resistente e produtiva. A Lavoura 620: 46-47.

Gallo, D.; O. Nakano; S. Silveira Neto; R. P. L. Carvalho; G. C. Batista; E. Berti Filho; J. R. P. Parra; R. A. Zucchi; S. B. Alves \& J. D. Vendramim.
1988. Manual de Entomologia Agrícola. São Paulo, Editora Agronômica Ceres, 3a ed., 649p.

Lorenzi, J. O.; T. L. Valle; D. A. Monteiro; V. A. Peressin \& R. A. D. KANTHACK. 1996. Variedades de mandioca para o Estado de São Paulo. Boletim Técnico do Instituto Agronômico de Campinas $\mathbf{1 6 2}$. $36 \mathrm{p}$.

Panizzi A. R. \& J. R. P. Parra. 1991. Ecologia Nutricional de Insetos e suas Implicações no Manejo de Pragas. São Paulo, Editora Manole, 359p.

PARRA, J. R. P. 2000. Técnicas de criação de insetos para programas de controle biológico. Piracicaba, Editora FEALQ/ESALQ, 138p.

Parra J. R. P. \& M. L. Haddad. 1989. Determinação do número de ínstares de insetos. Piracicaba, Editora FEALQ/ESALQ, 49p.

Pizzamiglio, M. A. 1991. Ecologia das Interações Inseto/Planta, p.101121. In: A. R. PANIZZI \& J. R. P. PARRA (eds.), Ecologia Nutricional de Insetos e suas Implicações no Manejo de Pragas. São Paulo, Editora Manole, 359p.

Silveira Neto, S.; O. Nakano; D. Barbin \& N. A. Villa Nova. 1976. Manual de Ecologia dos Insetos. Piracicaba, Editora Ceres, $1^{\circ}$ ed., 419p.

Ternes, M.; L. Miura \& A. T. Sсhmitt. 1984. Mandioca/Santa Catarina: Aspectos gerais e problemas da cultura. Correio Agrícola 3: 652655 . 